\title{
LRP1B Gene
}

National Cancer Institute

\section{Source}

National Cancer Institute. LRP1B Gene. NCI Thesaurus. Code C111830.

This gene plays a role in low density lipoprotein metabolism. 